\title{
Taxonomical and ecological characteristics of the desmids placoderms in reservoir: analyzing the spatial and temporal distribution
}

Características taxonômicas e ecológicas de desmidias placodermes em reservatório: analisando a distribuiçáo espacial e temporal

Sirlene Aparecida Felisberto ${ }^{1}$, Liliana Rodrigues ${ }^{2}$ and Helivânia Sardinha dos Santos ${ }^{2}$

${ }^{1}$ Programa de Pós-graduação em Biodiversidade Vegetal, Instituto de Ciências Biológicas - ICB, Universidade Federal de Goiás - UFG, CEP 74690-900, Goiânia, GO, Brazil email: fsirfe@gmail.com

${ }^{2}$ Programa de Pós-graduação em Ecologia de Ambientes Aquáticos Continentais - PEA - NUPÉLIA,

Universidade Estadual de Maringá - UEM, CEP 87020-900, Maringá, PR, Brazil

email: lilianarodrigu@gmail.com; helivania@gmail.com

\begin{abstract}
Aim: This study aimed to evaluate the influence of river-dam axis and abiotic factors on the composition of Closteriaceae, Gonatozygaceae, Mesotaeniaceae and Peniaceae in a tropical reservoir. Methods: Water samples for physical, chemical and periphyton analysis were collected in April and August 2002 in different regions along the axis of the river-dam of Rosana Reservoir, River Basin Paranapanema. The substrates collected, always in the litoranea region, were petioles of Eichhornia azurea (Swartz) Kunth. To examine the relationship of abiotic variables with reservoir zones and between the floristic composition of desmids, we used principal component analysis (PCA) and canonical correspondence analysis (CCA). Results: The results of the PCA explained $81.3 \%$ of the total variability in the first two axes. In the first axis, the variables of conductivity, water temperature and the $\mathrm{pH}$ were related to the sampling regions of April with higher values, while for the month of August, nitrate, total phosphorus and dissolved oxygen showed higher values. We identified 20 taxa, distributed in the genera Closterium (14), Gonatozygon (4), Netrium (1) and Penium (1). Spatially, the higher taxa were recorded in the lacustrine region for both collection periods. The canonical correspondence analysis (CCA) summarized $62.2 \%$ of total data variability of taxa in the first two axes, and in August, Closterium incurvum Brébisson, C. cornu Ehrenberg ex Ralfs and Gonatozygon monotaenium De Bary, were related to higher values of turbidity and nitrate to the lacustrine and intermediate regions. Conclusion: Thus, the formation of groups was due to the regions along the longitudinal axis, then the seasonal period, which must be related to the low current velocity, the higher values of temperature and the water transparency, especially in late summer.
\end{abstract}

Keywords: Zygnemaphyceae, periphytic algae, ecology, taxonomy.

Resumo: Objetivo: Com este trabalho objetivou-se avaliar a influência do eixo riobarragem e dos fatores abióticos sobre a composição de Closteriaceae, Gonatozygaceae, Mesotaeniaceae e Peniaceae em um reservatório tropical. Métodos: Amostras físicas e químicas da água e de perifíton foram coletadas nos meses de abril e agosto de 2002, em distintas regióes ao longo do eixo rio-barragem do reservatório de Rosana, Bacia do Rio Paranapanema. Os substratos coletados, sempre na região litorânea, foram pecíolos de Eichhornia azurea (Swartz) Kunth. Para analisar a relação das variáveis abióticas com as regiôes do reservatório e entre a composição florística de desmídias, realizou-se, respectivamente, análise de componentes principais (PCA) e análise de correspondência canônica (CCA). Resultados: Os resultados da PCA explicaram 81,3\% da variabilidade total nos dois primeiros eixos. No primeiro eixo, as variáveis condutividade, temperatura da água e $\mathrm{pH}$ estiveram relacionadas às regiôes amostrais de abril com maiores valores, enquanto para o mês de agosto nitrato, fósforo total e oxigênio dissolvido apresentaram maiores valores. Foram identificados 20 táxons, distribuídos nos gêneros Closterium (14), Gonatozygon (4), Netrium (1) e Penium (1). Espacialmente, maior riqueza de táxons foi registrada na região lacustre para ambos os períodos de coleta. A análise de correspondência canônica (CCA) resumiu $62,2 \%$ da variabilidade total dos dados dos táxons nos dois primeiros eixos, sendo que no mês de agosto, Closterium incurvum 
Brébisson, C. cornu Ehrenberg ex Ralfs e Gonatozygon monotaenium De Bary, estiveram relacionadas aos maiores valores de turbidez e nitrato para as regióes lacustre e intermediária. Conclusóes: Assim, a formação de grupos se deu em função das regiôes ao longo do eixo longitudinal, seguida do período sazonal, o que deve estar relacionado à menor velocidade de corrente, aos maiores valores de temperatura e transparência da água principalmente no fim do veráo.

Palavras-chave: Zygnemaphyceae, algas perifíticas, ecologia, taxonomia.

\section{Introduction}

Reservoirs can be described as a complex network between organisms and their physical and chemical environment, resulting from permanent responses to climatic forces functions and effects produced by manipulation of the system at the dam (Tundisi, 1999). Changing the status of the river conditions to the lake conditions, causes instability that can generate eutrophication due to the decomposition of plant material and nutrient input from an external source (Tundisi, 1999).

Studies show that the changes of physical and chemical parameters, associated, especially the change in the hydrological cycle, have a dominance of control between different species, and the rapid disappearance of phycoperiphyton in certain seasons (O'Reilly, 2006), especially during the filling phase of the reservoir, when the river is going to be altered (Felisberto et al., 2001; Felisberto and Rodrigues, 2002).

Among the periphytic algal, the desmids (Zygnemphyceae) constitute a representative group in number of genera and species. The desmids consist of microscopic green algae, which tend to have a cosmopolitan distribution, with most taxa confined in the oligotrophic environments to mesotrophic (Coesel, 1996). The Zygnemaphyceae, a relevant group in aquatic environments, with high morphological diversity compared to the other groups of green algae, comprise a large proportion of taxa in periphytic algal community.

The absences of structures to be fixed in the desmids substrates remain loosely attached to the substrate, but are part of the biofilm periphytic habitats. Thus, in this work, we hypothesized that due to these conditions of desmids in lake regions should have greater diversity and abundance of species. So, this study aimed to evaluate the influence of river-dam axis and abiotic factors on the composition and abundance of Closteriaceae, Gonatozygaceae, Mesotaeniaceae and Peniaceae in a tropical reservoir.

\section{Material and Methods}

\subsection{Study area description}

The Rosana Reservoir, whose hydroelectric was inaugurated in 1987, is situated in the basin of the Paranapanema river, which forms the border between the states of São Paulo and Paraná, between the coordinates, $22^{\circ} 36^{\prime} \mathrm{S}$ and $52^{\circ} 50^{\prime} \mathrm{W}$ (Figure 1). This reservoir represent $220 \mathrm{~km}^{2}$ of surface area, $116 \mathrm{~km}$ of long; $12 \mathrm{~m}$ of depth in the intermediate region and riverine, and $30 \mathrm{~m}$ in the lacustrine region.

The predominance of the uses of the watershed associated with rural environment (agriculture, pasture, reforestation and own settlements and farms), is significant, accounting for almost $80 \%$ of the entire watershed area (Nogueira et al., 2001).

\subsection{Sampling data}

For this work, samples were collected in 0911 April, and 27-29 August 2002. In relation to the longitudinal axis of the reservoir three sampling stations were established, located in the municipalities of Teodoro Sampaio (riverine), Euclides da Cunha (intermediate) and Rosana (lacustrine). The substrates collected, always in the litoranea region and in all sampling site were petioles of Eichhornia azurea (Swartz) Kunth. (a rooted macrophyte with several stands in the arms of Rosana Reservoir) and always in the adult stage. Afterwards, the periphyton was removed from the substrate with a razor blade and water jets distilled, transferred to $150 \mathrm{~mL}$ flasks, fixed and preserved with Transeau solution. Each petiole was measured using a caliper, converted in $\mathrm{cm}^{2}$, to obtain the area of the cylinder.

Abiotic data evaluated in the study were furnished by Limnology Laboratory, from Núcleo de Pesquisas em Limnologia, Ictiologia e Aquicultura - Nupélia. Water temperature and dissolved oxygen (YSI 55 portable oximeter), turbidity (LaMotte portable turbidimeter) and secchi disk were measured during the samplings. The concentrations of total nitrogen and total phosphorus were determined based on Valderrama 


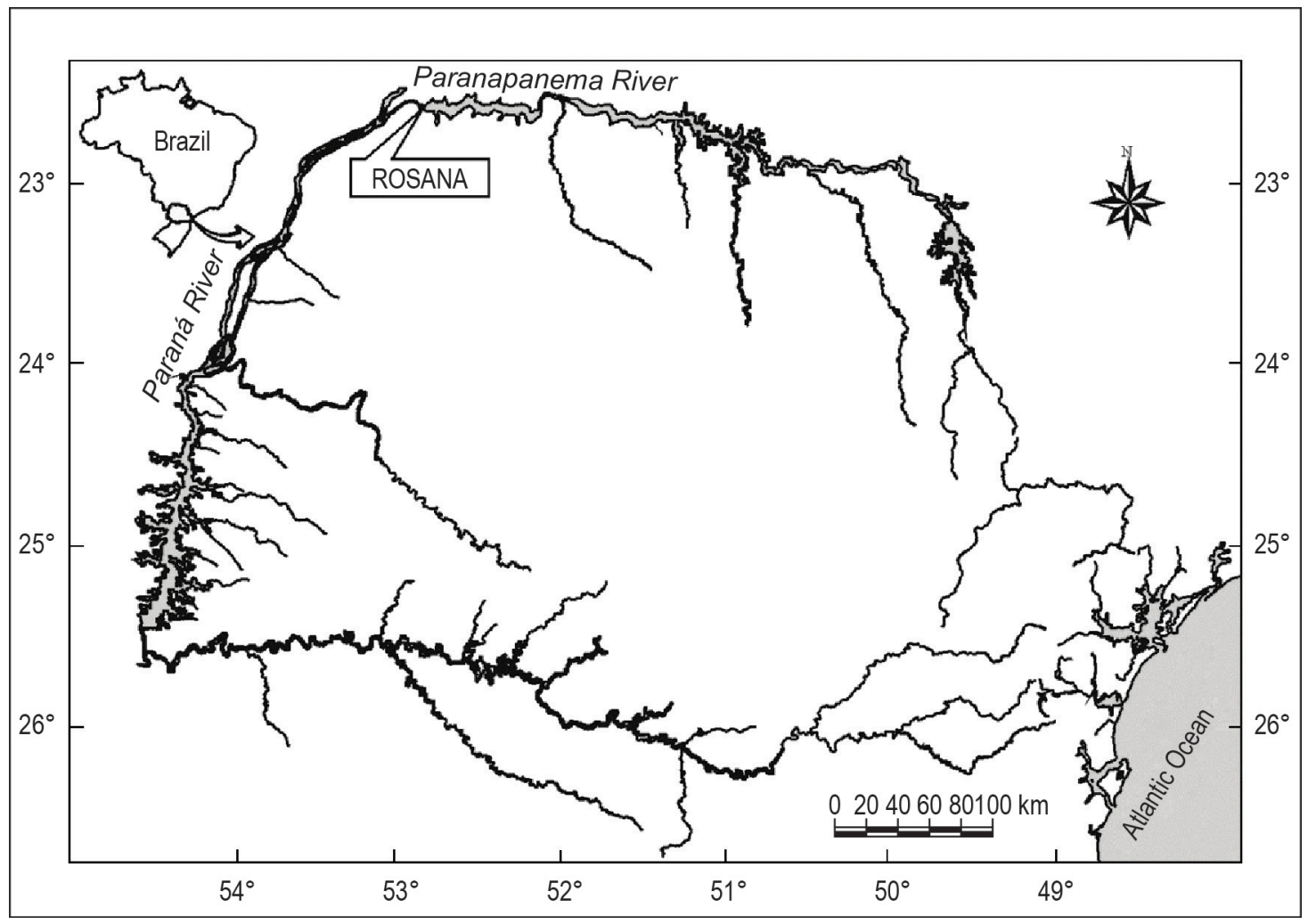

Figure 1. Map of the localization of Rosana Reservoir (River Paranapanema basin).

(1981), nitrate was estimated according to Mackereth et al. (1978).

\subsection{Presentation and data analysis}

All organisms were quantified using inverted microscope at 400X, according to Utermöhl (1958). Only live algae were counted for the densities calculation expressed in ind. $\mathrm{cm}^{-2}$. The density was calculated according to Ros (1979).

The taxonomical study of periphytic algae was accomplished using approximately 15 temporary slides, by samples. For this procedure, we used optical microscope with micrometric ocular. Cell measurements (in $\mu \mathrm{m}$ ) are indicated as follows: $\mathrm{W}=$ width, $\mathrm{L}=$ length. The samples are deposited in the herbarium of the Universidade Estadual de Maringá (HUEM) numbering from 15362 to 15367 , corresponding to the riverine region (15362), intermediate region (15363) and lacustrine region (15364) all in April/2002; riverine region (15365), intermediate region (15366) and lacustrine region (15367) all in August/2002.

The richness species, expressed in number of taxa for region, was obtained from qualitative samples complemented with quantitative samples. Dominant species were considered the species with densities greater than $50 \%$ of the total density of sample and, the abundance with densities greater than the mean densities of each sample (Lobo and Leighton, 1986).

The Principal Component Analysis (PCA) used to examine the longitudinal and seasonal variation relative to abiotic variables, was performed with nine variables $(\mathrm{pH}$, secchi disk, conductivity, turbidity, dissolved oxygen, water temperature, total nitrogen, nitrate, total phosphorus). For interpreting the results, we used the axes with eigenvalues higher than of the Broken-Stick model (suggested by Jackson, 1993), as a consistent assessment to determine the adequate number of components for interpretation.

The influence from the five abiotic variables (total nitrogen, nitrate, total phosphorus, turbidity and conductivity) on the periphytic desmids community structure was evaluated by a canonical correspondence analysis (CCA) with the significance by the Monte Carlo test $(\mathrm{p}<0.05)$, with 999 randomizations. For PCA and CCA, the variables were in $\log$ transformed and analyses were run with the software PC-ORD 5.15 (McCune and Mefford, 2006). 


\section{Results and Discussion}

\subsection{Spatial and temporal characterization}

The variable values accounted for $81.3 \%$ of the variance accumulated on the first two axes (62.3 and $19 \%$, respectively) (Table 1 ). The first axis variables conductivity, water temperature and $\mathrm{pH}$ were related sampling regions (intermediate and lacustrine) from April with higher values, while for the lacustrine from August, total phosphorus, nitrate and dissolved oxygen showed higher values (Figure 2).

Although it had a low value of explicability, axis 2 revealed a clear separation among seasonal periods (April and August), showing more homogeneous groups, especially in April for intermediate and

Table 1. Correlation and performance values obtained through Principal Component Analysis (PCA) to Rosana Reservoir from April to August/2002.

\begin{tabular}{lcc}
\hline \multicolumn{1}{c}{ Parameters } & $\begin{array}{c}\text { Axis 1 } \\
\text { correlation }\end{array}$ & $\begin{array}{c}\text { Axis 2 } \\
\text { correlation }\end{array}$ \\
\hline $\mathrm{pH}$ & 0.8048 & -0.4815 \\
Secchi & -0.8270 & -0.1291 \\
Conductivity & 0.9839 & -0.0826 \\
Turbidity & 0.7500 & 0.4174 \\
Dissolved oxygen & -0.7626 & -0.2670 \\
Water temperature & 0.8618 & -0.4625 \\
Total nitrogen & -0.4295 & -0.7113 \\
Nitrate & -0.8714 & -0.3908 \\
Total phosphorus & -0.6945 & 0.5790 \\
Eigenvalue & 5.613 & 1.709 \\
\% variance & 62.363 & 18.984 \\
Broken-stick & 2.829 & 1.829 \\
\hline
\end{tabular}

lacustrine regions. However, during August there was a separation between sampling sites from upstream of the reservoir (riverine) and from intermediate region of the reservoir, where they were more influenced by chemical variables, i.e. total phosphorus and turbidity (Figure 2).

The reservoirs of Paranapanema Basin show a pattern of variation defined by alternating between rainy season in summer and dry in winter (Nogueira et al., 2001). Thus, the rains influenced the differentiation of limnological variables in early April (Felisberto and Rodrigues, 2005b), and with the elevation of the water level, the intermediate region acquired more lentic conditions, resembling the lacustrine region.

This differentiation between regions within the reservoir also is related to the operation of the dam to generate electricity. Still, the longitudinal processes in reservoirs, usually associated with the residence time of water and allochthonous material input, promote the emergence of different regions along the axis-river dam, called lotic region, lentic and transition region (Thornton, 1990; Thomaz et al., 1997). So, the construction of reservoirs for various purposes has changed the natural ecosystems, and thus altered the physical and chemical conditions of lotic systems upstream, which can disturb the longitudinal gradients along river courses (Ward and Stanford, 1983; Straškraba et al., 1993; Silva et al., 2010).

Closteriaceae, Gonatozygaceae, Mesotaeniaceae and Peniaceae: Composition and abundance

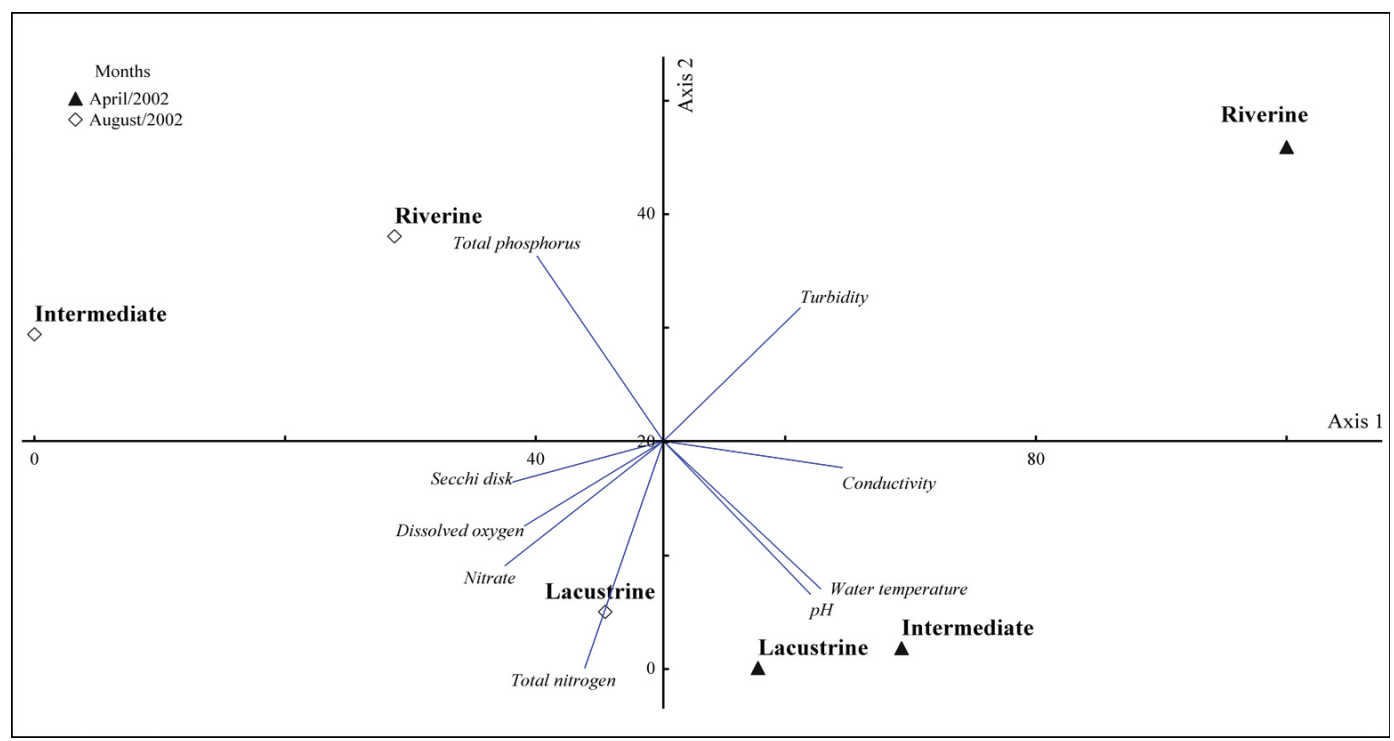

Figure 2. Principal Component Analysis (PCA) for physical and chemical parameters analyzed for the six sampling sites along the Rosana Reservoir, from April/2002 and August/2002. 
Periphytic desmids community in the Rosana Reservoir was comprised of 161 taxa and distributed into 18 genera (Felisberto and Rodrigues, 2005a). This total taxa, 20 were distributed in the genera of Closterium (14), Gonatozygon (4), Netrium (1), and Penium (1), which ones can be seen in Table 2.

Closterium calosporum Wittrock, Acta Soc. Sc. Upsal., Ser. 3 7(III): figs. 1-28. 1869.

Cells 5.9-7.4 times longer than wide, lunate with $90^{\circ}$ to $100^{\circ}$ arc; acuminate-rounded poles; smooth cell wall; axial chloroplast, 8 pyrenoids arranged in an axial axis. L: 67.5-75.7 $\mu \mathrm{m}$; W: 10-11.74 $\mu \mathrm{m}$.

\section{Figure 3A.}

Distribution in Brazil: Amazonas: Förster (1969). Bahia: Oliveira et al. (2013). Paraná: (Bittencourt-Oliveira and Castro (1993). Rio Grande do Sul: Ungaretti (1976). São Paulo: Bicudo and Castro (1994).

Closterium cornu Ehrenberg ex Ralfs, Brit. Desm., p. 176, pl. 30, figs. 6f-g. 1848.

Cells 9-12 times longer than wide, lunate almost straight; truncated poles; smooth cell wall; axial chloroplast, 2 pyrenoids arranged in an axial axis. L: 45-96 $\mu \mathrm{m}$; W: 5-6.5 $\mu \mathrm{m}$. Figure 3M.

Distribution in Brazil: Paraná: Felisberto and Rodrigues (2007); Bortolini et al. (2009). São
Paulo: Bicudo and Castro (1994); Sormus and Bicudo (1994).

Closterium dianae Ehrenberg ex Ralfs var. minus Hieronymus, Pflanzenw. Öst - Afrikas, p. 19. 1895.

Cells 8.4-9.6 times longer than wide, lunate with $120^{\circ}$ of arc; obtuse-rounded poles; smooth cell wall with polar thickening; axial chloroplast, 3 pyrenoids arranged in an axial axis. L: 92.9-100.8 $\mu \mathrm{m}$; W: 9.6-12 $\mu \mathrm{m}$. Figure 3B.

Distribution in Brazil: Amazonas: Lopes and Bicudo (2003). Paraná: Felisberto and Rodrigues (2007); Bortolini et al. (2010); Aquino et al. (2014).

Closterium exiguum West \& G.S. West, Trans. Linn. Soc. Lond., v. 6, p. 141, 1902.

Cells 10.2 times longer than wide, strongly curved, $160^{\circ}$ of arc; large cells in the middle region, strongly attenuated to the acute poles; smooth cell wall. L: $48.9 \mu \mathrm{m}$; W: $4.8 \mu \mathrm{m}$. Figure 3C.

Distribution in Brazil: Rio Grande do Sul: Sophia et al. (2005).

Closterium ehrenbergii Meneghini ex Ralfs var. immane Wolle, Bull. Torrey Bot. Club, p. 26, pl. 13. 1882 .

Cells 3.8-5.4 times longer than wide, lunate almost straight, with $60-80$ of arc, sometimes is

Table 2. Taxa of Closteriaceae, Gonatozygaceae, Mesotaeniaceae and Peniaceae found in the Rosana Reservoir and their respective occurrence on the regions: Riverine (R), Intermediate (I), Lacustrine (L).

\begin{tabular}{|c|c|c|c|c|c|c|}
\hline \multirow{2}{*}{$\begin{array}{c}\text { Months } \\
\text { Family/Species }\end{array}$} & \multicolumn{3}{|c|}{ April } & \multicolumn{3}{|c|}{ August } \\
\hline & $\mathbf{R}$ & I & $\mathbf{L}$ & $\mathbf{R}$ & I & $\mathbf{L}$ \\
\hline \multicolumn{7}{|l|}{ CLOSTERIACEAE } \\
\hline Closterium calosporum Wittrock & $\mathrm{x}$ & $\mathrm{x}$ & & & & \\
\hline Closterium cornu Ehrenberg ex Ralfs & & & & & & $x$ \\
\hline Closterium dianae Ehrenberg ex Ralfs var. minus Hieronymus & & & $x$ & & & \\
\hline Closterium ehrenbergii Meneghini ex Ralfs var. immane Wolle & $x$ & & & $x$ & & $x$ \\
\hline Closterium exiguum West \& West & & & $\mathrm{x}$ & & & \\
\hline Closterium incurvum Brébisson & $\mathrm{x}$ & $\mathrm{x}$ & $\mathrm{x}$ & $\mathrm{x}$ & $\mathrm{x}$ & $\mathrm{x}$ \\
\hline Closterium laterale Nordstedt & & & $\mathrm{x}$ & & & \\
\hline Closterium leibleinii Kützing ex Ralfs & $x$ & & $x$ & & & \\
\hline Closterium moniliferum (Bory) Ehrenberg ex Ralfs & $\mathrm{x}$ & & $\mathrm{x}$ & $\mathrm{x}$ & & \\
\hline Closterium tortum Griffiths & & & & $\mathrm{x}$ & $x$ & $x$ \\
\hline Closterium navicula (Brébisson) Lutkemuller & $x$ & & & & & $x$ \\
\hline Closterium tumidum Johnson var. nylandicum Grönbland & & $x$ & $x$ & & & $x$ \\
\hline Closterium venus Kützing ex Ralfs & $x$ & & $\mathrm{x}$ & & & \\
\hline Closterium venus Kützing ex Ralfs var. westii W. Krieger & & & $\mathrm{x}$ & $x$ & & \\
\hline \multicolumn{7}{|l|}{ GONATOZYGACEAE } \\
\hline Gonatozygon aculeatum Hastings & & & $\mathrm{x}$ & & & \\
\hline Gonatozygon brebissonii De Bary & & & $\mathrm{x}$ & $x$ & & $x$ \\
\hline Gonatozygon monotaenium De Bary & $x$ & $x$ & $\mathrm{x}$ & $x$ & & $x$ \\
\hline Gonatozygon pilosum Wolle & $x$ & $x$ & $\mathrm{x}$ & & & \\
\hline \multicolumn{7}{|l|}{ MESOTAENIACEAE } \\
\hline Netrium digitus (Ehrenberg) Itzigsohn \& Rothe & $x$ & $x$ & $x$ & & & \\
\hline \multicolumn{7}{|l|}{ PENIACEAE } \\
\hline \multirow[t]{2}{*}{ Penium margaritaceum (Ehrenberg) ex Brébisson } & $x$ & & $\mathrm{x}$ & $x$ & & \\
\hline & 11 & 06 & 15 & 08 & 02 & 08 \\
\hline
\end{tabular}



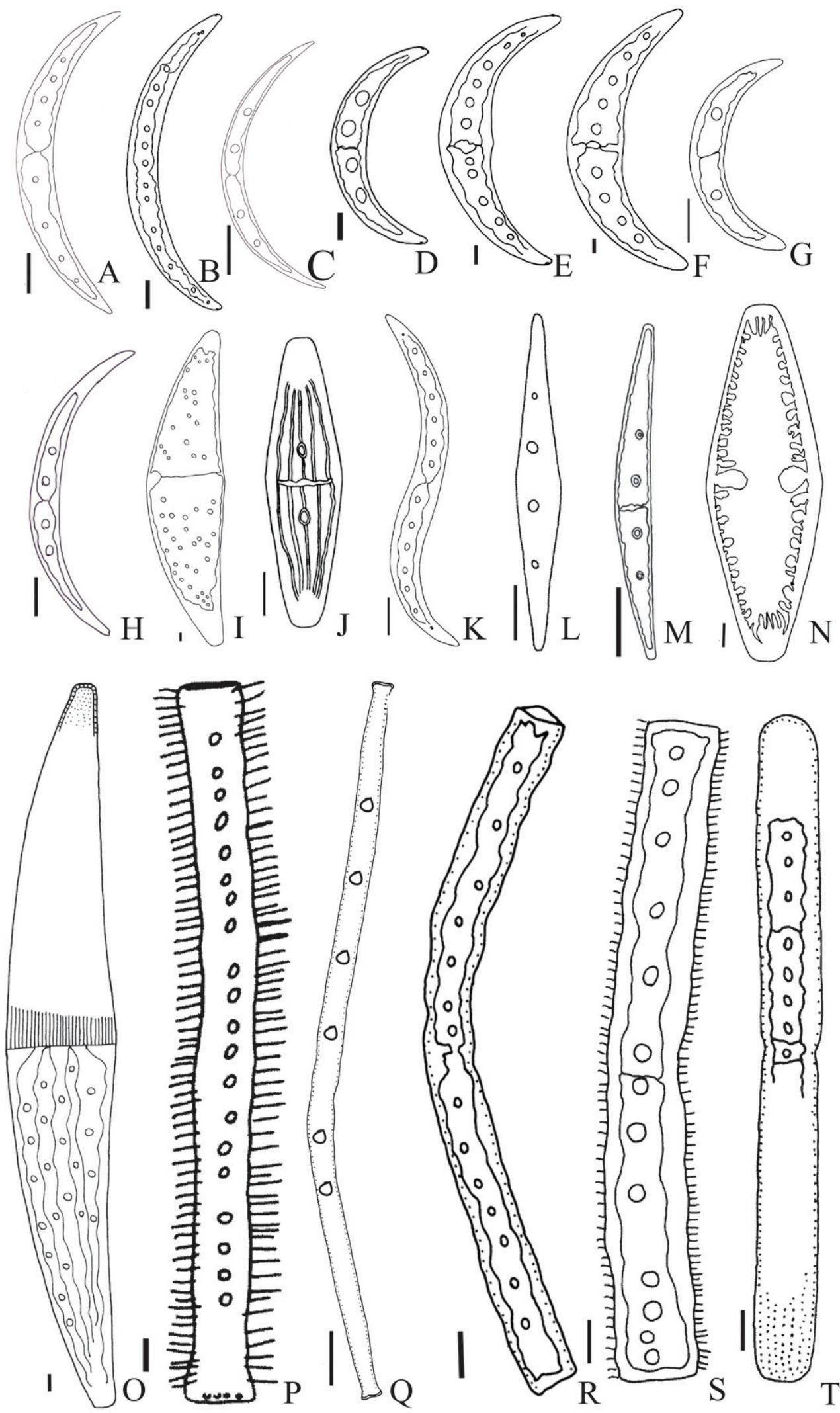

Figure 3. A: Closterium calosporum; B: C. dianae var. minus; C: C. exiguum; D: C. incurvum; E: C. leibleinii; F: C. moniliferum; G: C. venus; $\mathbf{H}:$ C. venus var. westii; $\mathbf{I}:$ C. ehrenbergii var. immane; $\mathbf{J}$ : C. navicula $\mathbf{K}:$ C. tortum; $\mathbf{L}:$ C. tumidum var. nylandicum; $\mathbf{M}$ : C. cornu, N: Netrium digitus; P: Gonatozygon aculeatum; Q: G. brebissonii; R: G. monotaenium; S: G. pilosum; T: Penium margaritaceum. Scar barrs $=10 \mu \mathrm{m}$. 
medially inflated; axial chloroplast, numerous pyrenoids dispersed. L: 323.4-408.6 $\mu \mathrm{m}$; W: 68.6$102.9 \mu \mathrm{m}$. Figure 3I.

Distribution in Brazil: Paraná: Felisberto and Rodrigues (2007).

Closterium incurvum Brébisson, Mém. Soc. imp. Sci. nat. Cherbourg, v. 4, p. 150, pl. 2, fig. 47. 1856.

Cells 4.7-6.6 times longer than wide, strongly curved, 160-170 of arc; rounded poles, smooth cell wall; axial chloroplast, 2-3 pyrenoids arranged in an axial axis. L: 52-104 $\mu \mathrm{m}$; W: 11-18 $\mu \mathrm{m}$. Figure 3D.

Distribution in Brazil: Amazonas: Lopes and Bicudo (2003); Cunha et al. (2013). Bahia: Oliveira et al. (2013). Paraná: Picelli-Vicentim (1984); Bittencourt-Oliveira and Castro (1993); Felisberto and Rodrigues (2007); Biolo et al. (2008); Bortolini et al. (2009); Bortolini et al. (2010). Rio Grande do Sul: Bicudo and Ungaretti (1986); Sophia et al. (2005). São Paulo: Bicudo and Castro (1994); Sormus and Bicudo (1994).

Closterium laterale Nordstedt, Wittr. \& Nordst. Alg., exsic. 8, n. 383. 1880.

Cells 7-8.3 times longer than wide, lunate almost straight; truncated poles; striated cell wall (12-13 in $10 \mu \mathrm{m})$; scores on cell apices, with polar thickening; axial chloroplast, numerous pyrenoids dispersed. L: 448.8-455.7 $\mu \mathrm{m}$; W: 54-68.8 $\mu \mathrm{m}$. Figure 30.

Distribution in Brazil: Paraná: Felisberto and Rodrigues (2007). São Paulo: Sormus and Bicudo (1994).

Closterium leibleinii Kützing ex Ralfs, Brit. Desm., p. 167, pl. 28, fig. 4. 1848.

Cells 2.5 times longer than wide, strongly curved, 160-170 of arc; sometimes is medially inflated; acuminate-rounded poles; smooth cell wall with polar thickening; axial chloroplast, 5-8 pyrenoids arranged in an axial axis. L: $98 \mu \mathrm{m}$; W: $38 \mu \mathrm{m}$. Figure 3E.

Distribution in Brazil: Minas Gerais: Soares et al. (2007). Paraná: Felisberto and Rodrigues (2007); Bortolini et al. (2009); Menezes et al. (2011). Rio Grande do Sul: Sophia et al. (2005). São Paulo: Bicudo and Castro (1994); Sormus and Bicudo (1994).

Closterium moniliferum (Bory) Ehrenberg ex Ralfs, Brit. Desm., p. 166, pl. 27, fig. 3. 1848.

Cells 5.6-5.8 times longer than wide, curved, $90-140^{\circ}$ of arc; sometimes medially inflated; acuminate-rounded poles; smooth cell wall; axial chloroplast, 4-7 pyrenoids arranged in an axial axis. L: 162.5-211.2 $\mu \mathrm{m}$; W: 31.2-38.4 $\mu \mathrm{m}$. Figure 3F.
Distribution in Brazil: Amazonas: Lopes and Bicudo (2003); Cunha et al. (2013). Bahia: Oliveira et al. (2013). Mato Grosso: Borge (1925); De-Lamonica-Freire and Heckman (1996). Paraná: Felisberto and Rodrigues (2007); Biolo et al. (2008); Bortolini et al. (2009); Aquino et al. (2014). São Paulo: Borge (1918); Bicudo and Bicudo (1962); Bicudo and Castro (1994); Sormus and Bicudo (1994). Rio de Janeiro: Marinho and Huszar (1990); Sophia (2009).

Closterium navicula (Brébisson) Lutkemuller, Beitr. Biol. Pfl. Breslau, v. 8, n. 3, p. 395, 405, 408. 1902.

Cells 3-4 times longer than wide, line, elliptical or fusiform; truncated-rounded poles; smooth cell wall; axial chloroplast, 1-3 pyrenoids arranged in an axial axis or dispersed. L: 56-69.6 $\mu \mathrm{m}$; W: 16-19.2 $\mu \mathrm{m}$. Figure 3J.

Distribution in Brazil: Amazonas: Förster (1969, 1974); Scott et al. (1965); Lopes and Bicudo (2003); Melo and Souza (2009). Bahia: Oliveira et al. (2013). Minas Gerais: Bicudo (1969); Soares et al. (2007). Pará: Scott et al. (1965); Förster (1969). Paraná: Felisberto and Rodrigues (2007); Bortolini et al. (2009); Menezes et al. (2011); Aquino et al. (2014). Rio de Janeiro: Bicudo and Picelli-Vicentim (1988); Sophia (2009). Rio Grande do Sul: Ungaretti (1981); Sophia et al. (2005). São Paulo: Borge (1918); Bicudo and Bicudo (1962); Bicudo (1969); Bicudo and Castro (1994); Sormus and Bicudo (1994).

Closterium tortum Griffiths, J Linn Soc Lond, p. 90, pl. 1, figs 4-6. 1925.

Cells 6.8-11 times longer than wide, sigmoid; acuminate poles; smooth cell wall; axial chloroplast, 6 pyrenoids arranged in an axial axis. L: 81.6-176 $\mu \mathrm{m}$; W: 12-16 $\mu \mathrm{m}$. Figure 3K.

Distribution in Brazil: Amazonas: Lopes and Bicudo (2003); Cunha et al. (2013).

Closterium tumidum Johnson var. nylandicum Grönblad, Acta Soc. Fauna Flora Fenn, p. 7, pl. 5, figs. 38-41. 1921.

Cells 7.8-12.3 times longer than wide, slightly curved, with a subfusiforme middle part, attenuating gradually to the apex; rounded truncated poles; axial chloroplast, 2-5 pyrenoids arranged in an axial axis. L: 56.4-77 $\mu \mathrm{m}$; W: 6-8 $\mu \mathrm{m}$. Figure 3L.

Distribution in Brazil: Amazonas: Cunha et al. (2013). São Paulo: Bicudo and Castro (1994).

Closterium venus Kützing ex Ralfs, Brit. Desm., p. 220, pl. 35, fig. 12. 1848.

Cells 5.2-7.3 times longer than wide, strongly curved, $160-170^{\circ}$ of arc; somewhat medially 
inflated, obtuse-rounded poles; smooth cell wall; axial chloroplast, 1-2 pyrenoids arranged in an axial axis. L: $42-49 \mu \mathrm{m}$; W: 6-8 $\mu \mathrm{m}$. Figure 3G.

Distribution in Brazil: Amazonas: Förster (1969). Bahia: Oliveira et al. (2013). Mato Grosso: Borge (1903, 1925). Rio Grande do Sul: Borge (1903). São Paulo: Bicudo and Bicudo (1962); Bicudo (1969); Sormus and Bicudo (1994).

Closterium venus Kützing ex Ralfs var. westii W. Krieger, p. 274, pl. 16, fig. 9. 1935.

Cells 8.2-11 times longer than wide, curved, $120-130^{\circ}$ of arc, attenuating gradually to the apex; acuminate poles; smooth cell wall; axial chloroplast, 1-2 pyrenoids arranged in an axial axis. L: 56.4-77 $\mu \mathrm{m}$; W: $6-8 \mu \mathrm{m}$. Figure $3 \mathbf{H}$.

Distribution in Brazil: first register.

Gonatozygon aculeatum Hastings, Amer. Month. Microsc. Jour., p. 29. 1892.

Cells 9-18.8 times longer than wide, cylindrical, elongate; apex dilated, truncate; thick apical angles, slightly rounded; cell wall ornamented with spines; 2 axial chloroplasts, with many pyrenoids. L: 204-323.4 $\mu \mathrm{m}$; W: 16-21.6 $\mu \mathrm{m}$; Spines: $10 \mu \mathrm{m}$. Figure 3P.

Distribution in Brazil: Amazonas: Förster (1969, 1974). Mato Grosso: Borge (1925).

Gonatozygon brebissonii De Bary, Untersuch. Conjugaten: 77, p. 28, pl. 4, figs. 26-27. 1858.

Cells 14.6-34.8 times longer than wide, elongate, fusiform; apex dilated, truncate; thick apical angles, slightly rounded; cell wall ornamented with granules, axial chloroplast, with $8-10$ pyrenoids. L: 88-198 $\mu \mathrm{m}$; W: 4-7.2 $\mu \mathrm{m}$. Figure 3Q.

Distribution in Brazil: Amazonas: Förster (1974).

Gonatozygon monotaenium De Bary, Alg. Sachsen: 539. 1856.

Cells 8-20 times longer than wide, cylindrical, elongate; apex slightly dilated, truncate; thick apical angles, slightly rounded; cell wall ornamented with granules, axial chloroplast, with 9-19 pyrenoids. L: 64-192 $\mu \mathrm{m}$; W: 8-12.5 $\mu \mathrm{m}$. Figure 3R.

Distribution in Brazil: Amazonas: Scott et al. (1965); Förster (1969). Mato Grosso: Borge (1903, 1925). Pará: Grönblad (1945). Paraná: Felisberto and Rodrigues (2008); Bortolini et al. (2010). Rio de Janeiro: Sophia (1991). São Paulo: Borge (1918); Bicudo (1969); Bicudo et al. (1997).

Gonatozygon pilosum Wolle, Bull. Torrey Bot. Club, p. 27, pl. 13, fig. 16. 1882.

Cells 8.2-14.2 times longer than wide, cylindrical, elongate; apex dilated, truncate; thick apical angles, slightly rounded; cell wall ornamented with thin spines, 1axial chloroplast, with 7-17 pyrenoids. L: $74.4-170.4 \mu \mathrm{m}$; W: 9.6-18 $\mu \mathrm{m}$. Figure 3S.

Distribution in Brazil: Amazonas: Förster (1969); Lopes and Bicudo (2003); Cunha et al. (2013). Paraná: Bortolini et al. (2010). São Paulo: Bicudo et al. (1997).

Netrium digitus (Ehrenberg) Itzigsohn \& Rothe, Alg. Sachsen, p. 508. 1856.

Cells 3.7-4.9 times longer than wide, elliptical, attenuated to the truncate-rounded apex; margins laterals convex; smooth cell wall, axial chloroplast, with longitudinal denticulate projections proeminent. L: 146-196.8 $\mu \mathrm{m}$; W: 38-49.5 $\mu \mathrm{m}$. Figure 3N.

Distribution in Brazil: Amazonas: Scott et al. (1965); Martins (1982). Mato Grosso: DeLamonica-Freire and Heckman (1996); Paraná: Bortolini et al. (2008); Felisberto and Rodrigues (2008); Bortolini et al. (2010). Rio de Janeiro: Bicudo and Bicudo (1969); Sophia (1991). Rio Grande do Sul: Ungaretti (1981); Rosa et al. (1987, 1988); Franceschini, 1992).

Penium margaritaceum (Ehrenberg) Brébisson ex Ralfs, Brit. Desm. 149. 1848.

Cells 10.4-17.8 times longer than wide; cylindrical, elongated, median constriction missing or not clear; round poles; cell wall irregularly punctuated. L: 146-213.6 $\mu \mathrm{m}$; W: 12-15 $\mu \mathrm{m}$. Figure 3T.

Distribution in Brazil: Paraná: Biolo et al. (2008); Aquino et al. (2014). Rio de Janeiro: Sophia (1991). Rio Grande do Sul: Sophia et al. (2005). São Paulo: Bicudo et al. (1997).

Among the 35 species with abundance in April, Closterium moniliferum and Gonatozygon monotaenium (two and three individuals; $\mathrm{cm}^{-2}$, respectively) were plenty found in the riverine region, while G. aculeatum (49) and G. brebissonii (48) were abundant in lacustrine region. Among the 19 species with abundance in August, Closterium moniliferum (19) and Gonatozygon monotaenium (64) were plenty found in the riverine and lacustrine regions, respectively (Felisberto and Rodrigues, 2005b).

Comparing the two samples analyzed in different regions of the Rosana Reservoir, the most taxa were recorded in the lacustrine region for both sampling periods (Table 2). Closterium incurvum was more frequent, being present in all regions (100\%), Gonatozygon monotaenium ocorred in $83.3 \%$ of regions, while Gonatozygon aculeatum, Closterium 
cornu, C. exiguum, C. dianae var. minus, and $C$. laterale showed only $16.6 \%$ of regions (Table 2 ).

The greater richness and relative abundance of species recorded in the lacustrine region of the Rosana Reservoir for both collection periods, parts must be related to the lentic water conditions, higher nutrients values, and the greater amount of substrate and water transparency (Felisberto and Rodrigues, 2005a, 2005b).

Furthermore, near of the tropics, the water temperature has values close to the optimum values for the development of desmids, i.e. around $25-30$ ${ }^{\circ} \mathrm{C}$ (Coesel and Wardenaar, 1990), this explains the diversity of flora, both in species and in genera. This fact was observed in the lacustrine region of Rosana Reservoir $\left(26.8^{\circ} \mathrm{C}\right.$, seen Felisberto and Rodrigues 2005a, 2005b).

The canonical correspondence analysis (CCA) summarized $62.2 \%$ of total data variability of taxa in the first two axes. In August, Closterium incurvum, C. Cornu, C. navicula, Gonatozygon monotaenium and Closterium ehrenbergii var. immane were related to higher values of total phosphorus and nitrate to the lacustrine and intermediate regions (Figure 4). Still in the first axes, in April, a group of species formed for Closterium dianae var. minus, C. exiguum, C. laterale, C. venus, Gonatozygon aculeatum and Penium margaritaceum were related to lacustrine region, with higher values of conductivity (Figure 4).

In the second axes, in April, a group of species formed for Closterium calosporum, Gonatozygon pilosum, C. tumidum var. nylandicum and Netrium digitus were related to intermediate region, with higher values of conductivity. While, in August the species Closterium moniliferum, C. venus var. westii and Gonatozygon brebissonii were related to riverine

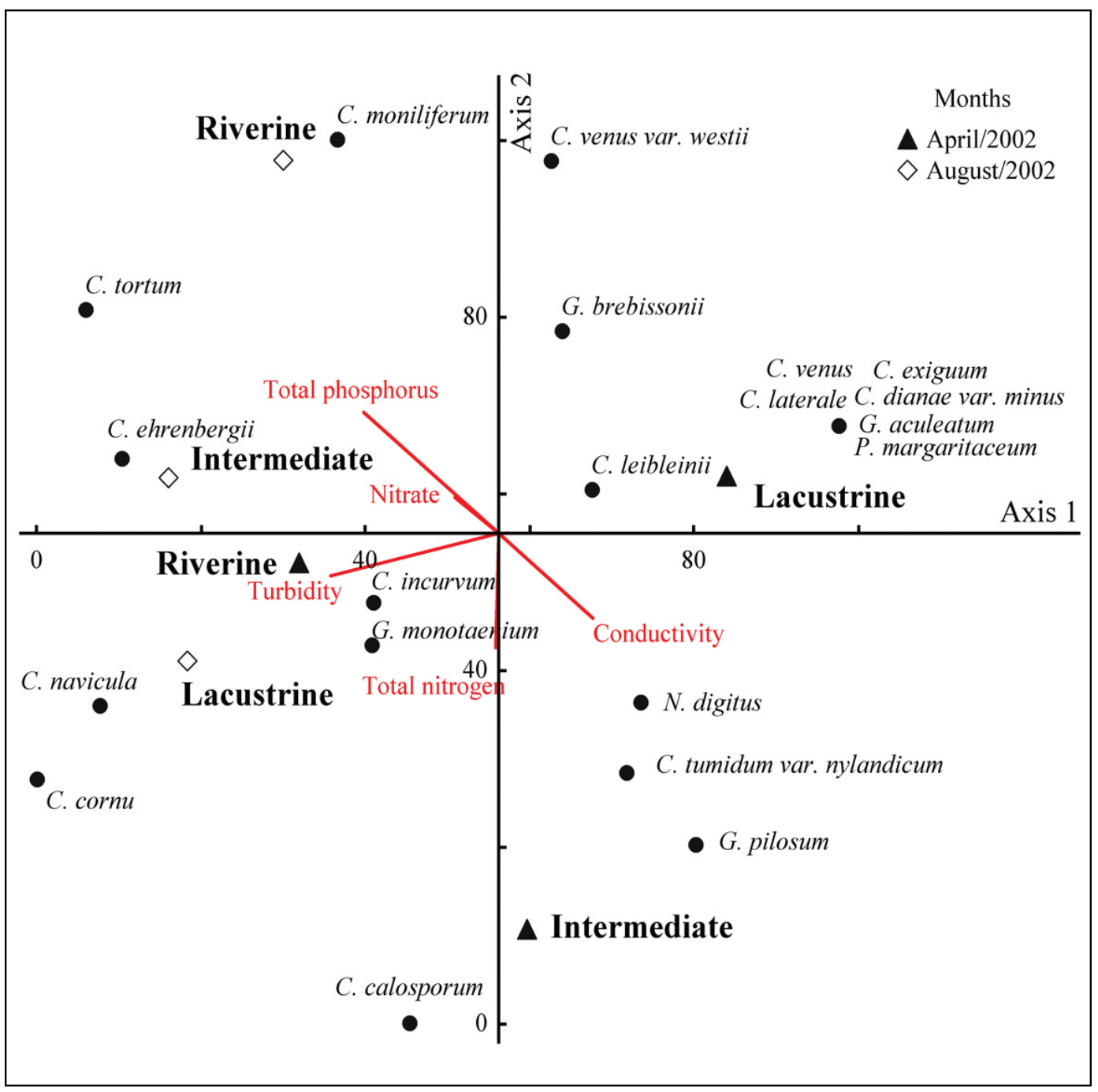

Figure 4. Ordination by the Canonical correspondence analysis (CCA) of abiotic variables and species, analyzed for the six sampling sites along the Rosana Reservoir, from April/2002 and August/2002. 
region, with higher values of total phosphorus (Figure 4).

Thus, besides the conditions evidenced in the CCA, the largest water transparency, lentic waters coupled with higher amount of substrate available for colonization of algae in the lacustrine and intermediate region benefited certain species, such as Closterium cornu, C. dianae var. minus, C. ehrenbergii var. immane. C. exiguum, C. incurvum, C. laterale, C. navicula, C. venus, Gonatozygon aculeatum, $G$. monotaenium and Penium margaritaceum.

Therefore, the formation of groups evidenced PCA and the CCA is given depending on the region along the longitudinal axis, then the seasonal period and relative abundance of species, which was related to increased availability of nutrients, turbidity, conductivity and diversity of substrate, lentic waters and higher water transparency mainly for the month of April (late summer and early fall). Closterium venus var. westii is first register for Brazil.

\section{Acknowledgements}

We are thankful the Núcleo de Pesquisas em Limnologia, Ictiologia e Aqüicultura - Nupélia, and PEA (Programa de Pós-Graduação em Ambientes Aquáticos Continentais) from the State University of Maringá, for the logistic, technical and scientific support during the accomplishment of this study; Conselho Nacional de Desenvolvimento Científico e Tecnológico (CNPq) for the first author scholarship and for the productivity scholarship to LR. This research is inserted in PRONEX Project 'Reservoir productivity: relationships with the trophic state and predation', developed by Nupélia.

\section{References}

AQUINO, CAN., BUENO, NC. and MENEZES, VC. 2014. Desmidioflórula (Zygnemaphyceae, Desmidiales) do rio Cascavel, Oeste do Estado do Paraná, Brasil. Hoehnea, vol. 41, no. 3, p. 365-392. http://dx.doi.org/10.1590/S223689062014000300005

BICUDO, CEM. and BICUDO, RMT. 1962. Contribuição ao conhecimento das Desmidiaceae do Parque do Estado, S. Paulo. Rickia, vol. 1, p. 207-225.

BICUDO, CEM. 1969. Contribution to the knowledge of the desmids of the State of São Paulo, Brazil (including a few from the State of Minas Gerais). Nova Hedwigia, vol. 17, no. 1-4, p. 446-570.

BICUDO, CEM. and BICUDO, RMT. 1969. Algas da lagoa das Prateleiras, Parque Nacional do Itatiaia, Brasil. Rickia, vol. 4, p. 1-40.

BICUDO, CEM. and UNGARETTI, I. 1986. Desmídias (Zygnemaphyceae) da Lagoa-Represa de Águas Belas, Rio Grande do Sul, Brasil. Revista Brasileira de Biologia, vol. 46, no. 2, p. 285-307.

BICUDO, CEM. and PICELLI-VICENTIM, MM. 1988. Ficoflórula do campo de esfagno das prateleiras, Parque Nacional de Itatiaia, sul do Brasil. Revista Brasileira de Biologia, vol. 48, p. 15-28.

BICUDO, CEM. and CASTRO, AAJ. 1994. Desmidioflórula paulista 4: gêneros Closterium, Spinoclosterium. Bibliotheca Phycologica, vol. 95, p. 1-191.

BICUDO, CEM., SORMUS, L. and SCHETTY, S. 1997. Criptógamos do Parque Estadual das Fontes do Ipiranga, São Paulo, SP. Algas, 9: Zygnemaphyceae (Peniaceae). Hoehnea, vol. 24, no. 1, p. 101-105.

BIOLO, S., SIQUEIRA, NS., BORTOLINI, JC. and BUENO, CB. 2008. Desmidiaceae (exceto Cosmarium) na comunidade perifítica em um tributário do Reservatório de Itaipu, Paraná, Brasil. Revista Brasileira de Biociências, vol. 6, p. 8-10. Supplement 1.

BITTENCOURT-OLIVEIRA, MC. and CASTRO, AAJ. 1993. Ficoflórula do Rio Tibagi, Estado do Paraná, Brasil, II: gênero Closterium (Zygnemaphyceae). Semina, Ciências Biológicas, vol. 14, p. 74-85.

BORGE, O. 1903. Die Algen der ersten Regnellschen Expedition, 2: Desmidiaceae. Arkiv För Botanik, vol. 1, p. 71-138.

BORGE, O. 1918. Die von Dr. Löfgr en in Sáo Paulo gessammelten Süsswosseralgen. Arkiv. För Botanik, vol. 15 , no. 13 , p. 1-108.

BORGE, O. 1925. Die von Dr. F.C. Hoehseewährend der Expedition Roosevelt-Rondon gesamnelten Süsswasseralgen. Arkiv För Botanik, vol. 19, no. 17, p. 1-56.

BORTOLINI, JC., MORESCO, C., SIQUEIRA, NS., BIOLO, S., MEURER, T. and BUENO, NC. 2008. Desmidiaceae do Lago Municipal de Cascavel, Paraná, Brasil. Revista Brasileira de Biociências, vol. 6, p. 19-21. Supplement 1.

BORTOLINI, JC., MORESCO, C., SIQUEIRA, NS., BIOLO, S. and BUENO, NC. 2009. Closterium Nitzsch ex Ralfs (Desmidiaceae) em um lago artificial urbano, Paraná, Brasil. Hoehnea, vol. 36, no. 3, p. 445-454. http://dx.doi.org/10.1590/S223689062009000300006

BORTOLINI, JC., MEURER, T. and BUENO, NC. 2010. Desmídias (Zygnemaphyceae) do Rio São João, Parque Nacional do Iguaçu, Paraná, Brasil. Hoehnea, vol. 37, no. 2, p. 293-313. http://dx.doi. org/10.1590/S2236-89062010000200005

COESEL, PFM. 1996. Biogeography of desmids. Hydrobiologia, vol. 336, no. 1-3, p. 41-53. http:// dx.doi.org/10.1007/BF00010818

COESEL, PFM. and WARDENAAR, K. 1990. Growth responses of planktonic desmid species in a temperature - light gradient. Freshwater 
Biology, vol. 23, no. 3, p. 551-560. http://dx.doi. org/10.1111/j.1365-2427.1990.tb00294.x

CUNHA, EDS., CUNHA, AC., SILVEIRA JUNIOR, AMS. and FAUSTINO, SMM. 2013. Phytoplankton of two rivers in the eastern Amazon: characterization of biodiversity and new occurrences. Acta Botânica Brasilica, vol. 27, no. 2, p. 364-377. http://dx.doi. org/10.1590/S0102-33062013000200011

DE-LAMONICA-FREIRE, EM. and HECKMAN, CW. 1996. The seasonal succession of biotic communities in wetlands of the tropical wet-and-dray climatic zone: III. The algal communities in the Pantanal of Mato Grosso, Brazil, with a comprehensive list of the known species and revision of two desmid taxa. Institut für Hydrobiologie und Fischereiwissenschaft, vol. 81, no. 2, p. 253-280.

FELISBERTO, SA., RODRIGUES, L. and LEANDRINI, JA. 2001. Chlorococcales registradas na comunidade perifítica, no reservatório de Corumbá, Estado de Goiás, Brasil, antes e após o represamento das águas. Acta Scientiarum: Biological Sciences, vol. 23, no. 2, p. 275-282.

FELISBERTO, SA. and RODRIGUES, L. 2002. Desmidiales (exceto o gênero Cosmarium) perifíticas no reservatório de Corumbá, Goiás, Brasil. Iheringia, Série Botânica, vol. 57, p. 75-97.

FELISBERTO, SA. and RODRIGUES, L. 2005a. Influência do gradiente longitudinal (rio-barragem) na similaridade das comunidades de desmídias perifíticas. Revista Brasileira de Botânica, vol. 28, no. 2, p. 241-254.

FELISBERTO, SA. and RODRIGUES, L. 2005b. Abundance of periphytic desmids in two Brazilian reservoirs with distinct environmental conditions. Acta Limnologica Brasiliensia, vol. 17, no. 4, p. 433443.

FELISBERTO, SA. and RODRIGUES, L. 2007. Gênero Closterium (Closteriaceae) na comunidade perifítica do Reservatório de Salto do Vau, sul do Brasil. Iheringia, Série Botânica, vol. 62, no. 1-2, p. 45-54.

FELISBERTO, SA. and RODRIGUES, L. 2008. Desmidiaceae, Gonatozygaceae e Mesotaeniaceae na comunidade perifítica do reservatório de Salto do Vau (Bacia do rio Iguacu, PR). Hoehnea, vol. 35, no. 2, p. 235-254. http://dx.doi.org/10.1590/S223689062008000200006

FÖRSTER, K. 1969. Amazonian Desmids. 1st part. Area Santarém. Amazoniana, vol. 2, p. 5-232.

FÖRSTER, K. 1974. Amazonische Desmidieen, 2 Areal Maués-Abacaxis. Amazoniana, vol. 5, p. 135-242.

FRANCESCHINI, LM. 1992. Algues d'eau douce de Porto Alegre, Brésil (les Diatomophycées exclues). Bibliotheca Phycologica, vol. 92, p. 1-81.

GRÖNBLAD, R. 1945. De algis brasiliensibus praecipue Desmidiaceis in regione inferiore fluminis Amazonas, a Professor August Ginzberger (Wien) ano
MCMXXVII collectis. Acta Societatis Scientiarum Fennicae, Séries B, vol. 2, no. 6, p. 1-43.

JACKSON, DA. 1993. Stopping rules in principal components analysis: a comparison of heuristical and statistical approaches. Ecology, vol. 74, p. 2204-2214. http://dx.doi.org/10.2307/1939574

LOBO, E. and LEIGHTON, G. 1986. Estructuras de las fitocenosis planctónicas de los sistemas de desembocaduras de rios y esteros de la zona central de Chile. Revista de Biologia Marina, vol. 22, p. 1-29.

LOPES, MRM. and BICUDO, CEM. 2003. Desmidioflórula de um lago da planície de inundação do Rio Acre, Estado do Amazonas, Brasil. Acta Amazonica, vol. 32, no. 3, p. 167-212.

MACKERETH, FJH., HERON, J. and TALLING, JF. 1978. Water analysis: some revised methods for limnologists. Ambleside: Scientific Publication.

MARINHO, MM. and HUSZAR, VLM. 1990. Estrutura da comunidade fitoplanctônica da Lagoa de Juturnaíba, Araruama, Rio de Janeiro, Brasil: uma comparação entre o centro da região limnética, tributários e canal de drenagem. Revista Brasileira de Biologia, vol. 50, no. 2, p. 107-123.

MARTINS, DV. 1982. Desmidioflórula dos lagos Cristalino e São Sebastião, Estado do Amazonas: gêneros Netrium, Closterium e Pleurotaenium. Acta Amazonica, vol. 12, no. 2, p. 279-290.

MCCUNE, B. and MEFFORD, MJ. 2006. PC-ORD: multivariate analysis of ecological data. Version 5.14. Gleneden Beach: MJM Software.

MELO, S. and SOUZA, KF. 2009. Flutuação anual e interanual da riqueza de espécies de desmídias (Chlorophyta - Conjugatophyceae) em um lago de inundação amazônico de águas pretas (Lago Cutiuaú, Estado do Amazonas, Brasil). Acta Scientiarum: Biological Sciences, vol. 31, no. 3, p. 235-243.

MENEZES, VC., BUENO, NC. and BORTOLINI, JC. 2011. Composição florística de Desmidiales (exceto Cosmarium) em um lago subtropical brasileiro. Revista Brasileira de Biociências, vol. 9, no. 4, p. 465-476.

NOGUEIRA, MG., VIANA, NC., JORCIN, A. and BRITTO, YT. 2001. Limnologia comparada de 8 reservatórios em cascata no rio Paranapanema (SP-PR), Brasil. In Seminário Internacional Gestión Ambiental e Hidroelectricidad. Argentina: CACIERCTMSG. p. 1-20. CD-ROM.

OLIVEIRA, IB., BICUDO, CEM. and MOURA, CWN. 2013. New records and rare taxa of Closterium and Spinoclosterium (Closteriaceae, Zygnematophyceae) to Bahia, Brazil. Iheringia, Série Botânica, vol. 68, no. 1, p. 115-138.

O'REILLY, CM. 2006. Seasonal dynamics of periphyton in a large tropical lake. Hydrobiologia. vol. 553, p. 293-301. http://dx.doi.org/10.1007/s10750005-0878-x 
PICELLI-VICENTIM, MM. 1984. Desmidias (Zygnemaphyceae) planctônicas do Parque Regional do Iguaçu, estado do Paraná, Brasil: contribuição ao levantamento. Curitiba Universidade Federal do Paraná. [Dissertação de Mestrado].

ROS, J. 1979. Prácticas de ecologia. Barcelona: Omega. $181 \mathrm{p}$.

ROSA, ZM., TORGAN, LC., LOBO, EA. and HERZOG, LAW. 1987. Ficoflórula de ambientes lênticos, estudo preliminar da Região de Charqueadas, Rio Grande do Sul, Brasil, com vistas à avaliação ambiental. Acta Botanica Brasilica, vol. 1, no. 2, p. 165-188. http://dx.doi.org/10.1590/S010233061987000200006

ROSA, ZM., TORGAN, LC., LOBO, EA. and HERZOG, LAW. 1988. Análise da estrutura de comunidades fitoplanctônicas e de alguns fatores abióticos em trecho do Rio Jacuí, Rio Grande do Sul, Brasil. Acta Botanica Brasilica, vol. 2, no. 1-2, p. 31-46. http://dx.doi.org/10.1590/S010233061988000100003

SCOTT, AM., GRÖNBLAD, R. and CROASDALE, HT. 1965. Desmids from the Amazon Basin, Brazil, collected by Dr. H. Sioli. Acta Botanica Fennica, vol. 69, p. 3-93.

SILVA, WJ., FELISBERTO, SA., FONSECA, CP. and SOUZA, MGM. 2010. Serial discontinuity along the Descoberto River Basin, Central Brazil. Acta Limnologica Brasiliensia, vol. 22, no. 3, p. 344-355. http://dx.doi.org/10.1590/S2179975X2010000300011

SOARES, MCS., SOPHIA, MG. and HUSZAR, VLM. 2007. Phytoplankton flora of two rivers in Southeast Brazil - Paraibuna and Pomba Rivers, Minas Gerais. Revista Brasileira de Botânica, vol. 30, no. 3, p. 433450.

SOPHIA, MG. 1991. Desmídias de hábito solitário (exceto Micrasterias C. Agardh ex Ralfs) do município do Rio de Janeiro e arredores, Brasil. Revista Brasileira de Biologia, vol. 51, no. 1, p. 85-107.

SOPHIA, MG., DIAS, IC. and ARAÚJO, AM. 2005. Chlorophyceae and Zygnemaphyceae from the Turvo State Forest Park, state of Rio Grande do Sul, Brasil. Iheringia, Série Botânica, vol. 60, no. 1, p. 25-47.

SOPHIA, MGL. 2009. Algas subaereas: biodiversidade de desmidias no município de Rio de Janeiro e arredores, e estrutura de comunidades em encostas sob diferentes açôes antrópicas. Rio de Janeiro: Universidade Federal do Rio de Janeiro. [Tese de Doutorado].
SORMUS, L. and BICUDO, CEM. 1994. Criptógamos do Parque Estadual das Fontes do Ipiranga, São Paulo, SP. Algas, 6: Zygnemaphyceae (Closteriaceae). Hoehnea, vol. 21, no. 1-2, p. 75-92

STRAŠKRABA, M., TUNDISI, JG. and DUNCAN, A. 1993. State-of-the-art of reservoir limnology and water quality management. In STRAŠKRABA, M., TUNDISI, JG. and DUNCAN, A., eds. Comparative reservoir limnology and water quality management. Dordrecht: Kluwer Academic Publishers. p. 213-288.

THOMAZ, SM., BINI, LM. and ALBERTI, SM. 1997. Limnologia do Reservatório de Segredo: padróes de variação espacial e temporal. In AGOSTINHO, AA. and GOMES, LC., eds. Reservatório de Segredo: Bases ecológicas para o manejo. Maringá: EDUEM. p. 19-38.

THORNTON, KW. 1990. Perspectives on reservoir limnnology. In THORNTON, KW., KIMMEL, BL. and PAYNE, FE., eds. Reservoir limnnology: ecological perspectives. New York: John Wiley \& Sons. p. 1-15.

TUNDISI, JG. 1999. Reservatórios como sistemas complexos: teoria, aplicaçóes e perspectivas para usos múltiplos In HENRY, R., ed. Ecologia de reservatórios: estrutura, função e aspectos sociais. Botucatu: FUNDIBIO. p. 31-38.

UNGARETTI, I. 1976. Contribuição ao inventário das desmidias (Zygnemephyceae) do arroio do Dilúvio, Rio Grande do Sul, Brasil. Porto Alegre: Universidade Federal do Rio Grande do Sul. [Dissertação de Mestrado].

UNGARETTI, I. 1981. Desmídias (Zygnemaphyceae) de um açúde do Morro Santana, Porto Alegre, Rio Grande do Sul, Brasil. Iheringia, Série Botânica, vol. 27, p. 3-26.

UTERMÖHL, H. 1958. Zur vervollkommung der quantitativen phytoplankton-methodik. Internationalen Vereinigung fur Theoretische und Angewandte Limnologie, vol. 9, p. 1-38.

VALDERRAMA, JC. 1981. The simultaneous analysis of total nitrogen and total phosphorus in natural waters. Marine Chemistry, vol. 10, no. 2, p. 109-122. http:// dx.doi.org/10.1016/0304-4203(81)90027-X

WARD, JV. and STANFORD, JA. 1983. The serial discontinuity concept of lotic ecosystems. In FONTAINE III, TDI. and BARTELL, SM., eds. Dynamics of lotic ecosystems. Michigan: Ann Arbor Science. p. 29-42. 